\title{
John T. Ngo
}

A chemogenetic tool for biologists; how to be a scientist and a gardener.

W hen Nobel laureate Roger Tsien gave a talk at the California Institute of Technology, John Ngo was in the audience, then a PhD student in the lab of chemist David Tirrell. Ngo heard Tsien describe NS3 as a "selfimmolating protease" and Tsien acted out his explanation of the protease: he opened his arms and said the full-length polyprotein stretched from fingertip to fingertip. Tsien's head, Ngo recalls him saying, represented the NS3 protease native to the hepatitis $\mathrm{C}$ virus (HCV) that chops itself off from the larger protein. That would be if Tsien's head were to chew off his arms at the shoulders.

Ngo was later a postdoctoral fellow in Tsien's lab. "Watching him in the lab, it was incredible," he says. Tsien knew the details in multiple disciplines and was able to synthesize a molecule using the latest reaction published one week prior. "I hope to be one-tenth as good as Roger one day," he says.

\section{They were teaching me by just being who they are.}

After his postdoc, Ngo joined the faculty at Boston University, where he does many types of bioengineering. "My intuition is rooted around molecules, what they look like, how they work particularly, and with respect to proteins," he says. Ngo and his lab have now repurposed the protease NS3, which the virus uses to replicate and which makes it the target of a number of anti-HCV drugs.

Using an established anti-HCV drug, the team developed ligand-inducible connection, or LInC. It's a drug-inducible method that harnesses a domain of NS3 and the drug's binding specificity to tightly control an engineered protein in mammalian cells ${ }^{1}$. The protease holds things together in a fusion construct, the drug stops the NS3 cleavage, and the engineered protein remains intact and can affect gene expression.

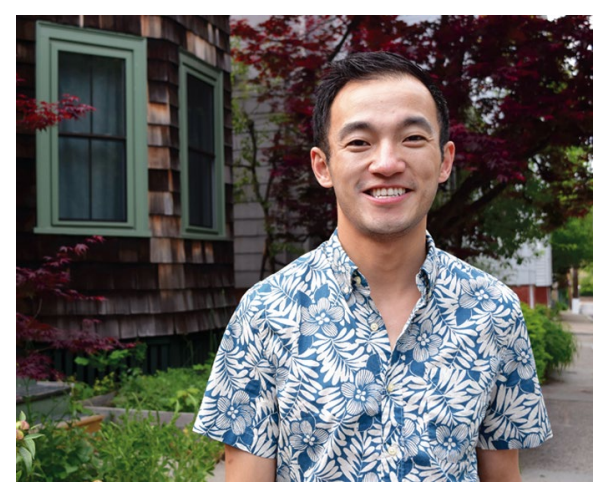

John T. Ngo (Photo: E. Martin)

The researchers used LInC to target engineered promoters and also to regulate endogenous promoters by integrating the LInC module into a construct with dead Cas9. They were able to alter gene expression in a drug-inducible fashion.

The work, says Ngo, is related to findings from the Tsien lab and results from another former Tsien lab postdoc, Stanford researcher Michael Lin, whose work also appears in this issue. Ngo believes LInC has advantages over other inducible systems such as tetracycline-based systems used in the lab because those systems can have off-target effects. "In the ideal case we'd like the drug to bind the protein that we've engineered and essentially no other proteins in the human system," he says. LInC can be used for synthetic biology applications and, potentially, in cellular-based therapies in which cells are used as therapeutic agents.

Ngo believes more methods like these will emerge and help labs get ever-finer control of systems. The methods can be used in combination. "I'd like to use them to control cells in various different ways," he says, much like fluorescent proteins can be combined to create a "beautiful palette." The new methods will emerge from any number of labs, perhaps also his, he says. Now, as a mentor, he has flashbacks to his training and sees much better what his mentors, Tirrell and Tsien, were teaching him. "I see the lessons that come out every day," he says.

These moments occurred when he did experiments and they happen now, too, as he coaches others. "They were teaching me by just being who they are," he says of his mentors. The lessons involve the many aspects of doing science, including, he says, "how to wrap your head around a problem, how to take a series of failed experiments and extract information from those experiments so you can fix the next series." As a trainee, he was eager to get papers out, but his mentors asked him also to focus deeply on science and on the long term. They taught him, says Ngo, how to develop an inquisitive and critical mind as a scientist.

Ngo wants to create methods for the community to advance science and he wants to train scientists who will push boundaries. "I'm helping them put their puzzles together just like Dave and Roger helped me," he says. "That's my favorite part of this whole job and process."

Outside of the lab, Ngo enjoys gardening. "I love plants," he says. "It's almost like doing an experiment at home." In Southern California, he enjoyed working year round with succulents and desert plants. The Boston springtime brings dramatic transitions in grass, trees, and many flowers that don't grow in California.

"John is among the most imaginative people I've ever met," says Tirrell, who was Ngo's PhD advisor at Caltech. This imaginative ability, he says, shows up in the creativity of his work and in a great sense of humor that also pervades his commentary on day-to-day life.

\section{Vivien Marx}

Published online: 2 July 2018

https://doi.org/10.1038/s41592-018-0047-6

References

1. Tague, E. P. et al. Chemogenetic control of gene expression and cell signaling with antiviral drugs Nat. Methods https://doi. org/10.1038/10.1038/s41592-018-0042-y (2018). 